\title{
Critical Review and Improvement of Bank Protection Methods in Nepalese Rivers
}

\author{
Mukesh Raj Kafle \\ Department of Civil Engineering, Pulchowk Campus, Institute of Engineering, Tribhuvan University, Nepal \\ Corresponding Author: mkafle@pcampus . edu.np
}

Received: 2020-08-07

Revised: 2021-01-26

Accepted: 2021-02-05

\begin{abstract}
:
This paper reviews performance of bank protection works constructed over the last decades along the major rivers in Nepal. The study reveals main reasons of early spurs failure in five major rivers - Koshi, Narayani, West Rapti, Karnali and Mahakali. The overview finds design deficiency as the main reason of failure of bank protection works. The methodology incorporates a combination of field visits and a review of design reports, master plans. The study finds bank protection works along the major rivers in Nepal consist almost exclusively of spurs often combined with revetments in between, made of gabions filled with boulders. Also, the launching aprons are constructed of gabions. The lifetime of these bank protection works is less than 10 years and often much shorter. Designs are based on standard designs from Indian standards, developed for normal alluvial rivers. The study recommends initiating a bank protection pilot project to identify the cause of failure of the bank protection works and to test remedial measures for the sustainability enhancement of river protection works in future.
\end{abstract}

Keywords: Rivers, protection works, spurs, Indian Standards, master plan

\section{Introduction}

Nepal is one of the worst flood-affected countries and frequently suffers from different kinds of water-induced disasters like landslides, debris flow, flooding and sedimentation [1]. Floods are the recurrent phenomena of Nepal. Every year, the records of extensive damage to infrastructure, environment, economy and devastation of human settlements are soaring. These floods are mainly occur due to mechanisms of continuous rainfall and cloudburst, glacial lake outburst floods (GLOFs), landslide dam outburst floods (LDOFs), floods triggered by the failure of infrastructure, and sheet flooding or inundation in lowland areas due to an obstruction imposed against the flow [2]. The rivers that cause much of flooding in the Terai plain are Mechi (Mahakali), Karnali, West Rapti, Narayani, Bagamati and Koshi. All these rivers are perennial and snow fed originated from high mountains and Himalayas.

The most common planform types of rivers are meandering and braided, because of the high sediment loads and the subsequent steep slopes. More downstream, the rivers change in meandering ones they reduce their slope after depositing part of their sediment load. Those rivers attain their stability by changing its course. The morphology of a river is a strong determinant of flow, and can thus serve to intensify or mitigate flood waves and torrents. At the same time, when rivers flow in an alluvial plain they often become meandered or braided, and at times of flood, this morphology leads to excessive bank cutting which can destroy agricultural land and human settlements.

To improve a river and its banks structural measures are applied and termed as river training. River training is an important component in the prevention and mitigation of flash floods and general flood control, as well as in other activities such as ensuring safe passage of a flood under a bridge [3]. River training measures also reduce sediment transportation and thus minimize bed and bank erosion. Different techniques can be applied to protect eroding riverbanks. River-training structures can be classified into two main categories: transversal protection structures and longitudinal protection 


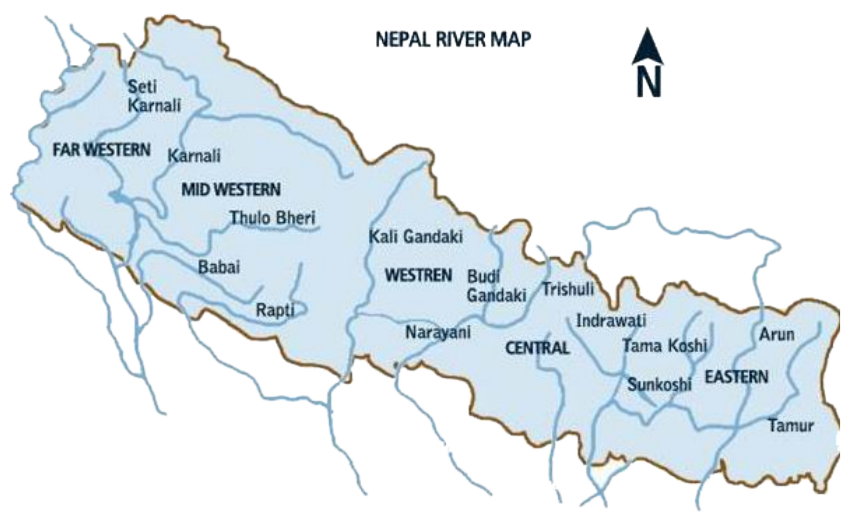

Figure 1: Index map showing the study area

structures. The selection and design of the most appropriate structure depends largely on the site conditions.

Limited researchers have discussed about these methods $[4,5,6,7,8]$. Transverse measures include spurs, check dams, sills, beam dams etc. Longitudinal measures incorporates levees, Porcupines and guide banks etc. Nepal has been practicing to adopt both river training measures in major Terai rivers. Permeable structures as a river training tool tend to be cheaper [9]. Few cost effective methods applied for river training are bandalling, board fencing, jack-jetty systems and tetrahedral frames $[10,11,12,13]$. Porcupine Systems have also been deployed in large rivers like Brahmaputra and Ganga with fairly good results [14].

Traditional efforts at flood management in the Indian subcontinent have focused on physical measures, such as the building of a system of embankments (all types of river control structures), many of which are poorly constructed and maintained. Also along the Terai Rivers in Nepal increasingly embankments are being built. For most of the Terai rivers a so-called master plan has been developed which aims at fully embanking the various rivers. Many of the bank protection structures have quickly failed to function as they should be. Hence, reviewing the design, construction and maintenance of bank protection works to see whether some insight into the possible causes of the quick failure of many of the bank protection works would be helpful in further improvement.

\section{Study area}

This study covers major five rivers namely Koshi, Narayani, West Rapti, Karnali and Mahakali [Figure 1].

\subsection{Koshi River}

This River originates at an elevation of $7000 \mathrm{~m}$ amsl from the plateau of Tibet (China). It traverses a distance of $470 \mathrm{~km}$ through the mountains, hills and terai plane of Nepal and Tibet before entering in Indian Territory of Bihar state. This is a snow-fed perennial river and one of the major tributaries of the river Ganges. The total catchment of the Koshi basin is $69,300 \mathrm{~km}^{2}(29000$ $\mathrm{km}^{2}$ in China; north of Mount Everest region, 30,700 $\mathrm{km}^{2}$ in Nepal and 9,200 $\mathrm{km}^{2}$ in India). The river is known as Sapta Koshi (seven Koshi) as it drains seven rivers from Nepal [Figure 2]. At the confluence of these tributaries, rivers drain through the narrow gorge for about $10 \mathrm{~km}$ and debouch into the plains near Chatara, Sunsari District, Nepal. After flowing $58 \mathrm{~km}$ through the plain of Nepal, it enters India near Bhimnagar. A further $260 \mathrm{~km}$ downstream from Bhimnagar, it joins the Ganga River in Kursela.

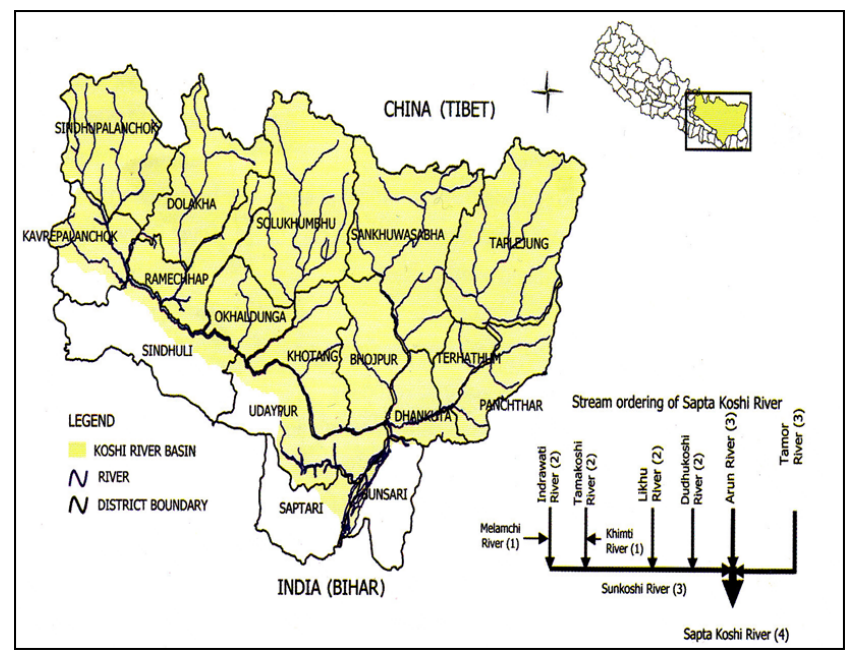

Figure 2: Koshi River basin (adopted from WWF)

\subsection{Narayani River}

Narayani River is a major perennial snow-fed river in Nepal. It originates in the high Himalayan range with the large numbers of tributary [Fig.3]. It emerges from north to south south with deep gorge between Chitwan and Nawalparasi districts before entering into Indian territory. It is a highly sediment laden river. It erodes and inundates hundreds of hectares of land in Terai. Major tributaries of the Narayani River are Kali Gandaki, Seti Gandaki, Marsyangdi and Trisuli River. The Narayani River is located in Dun area and surrounded by the Siwalik Hills. The East Rapti River joins to the Narayani River in the Dun area. The River has total basin area of $35,780 \mathrm{~km}^{2}$ near Indo-Nepal border. It has perennial 
snow fed characteristics with a length of $360 \mathrm{~km}$. In the Terai plains, its length is about $83 \mathrm{~km}$., with a basin area of some $705 \mathrm{~km}^{2}$. The East Rapti River joins it and these rivers form two boundary lines of the Chitwan National Park, one of the few remaining areas of natural vegetation in the Terai.

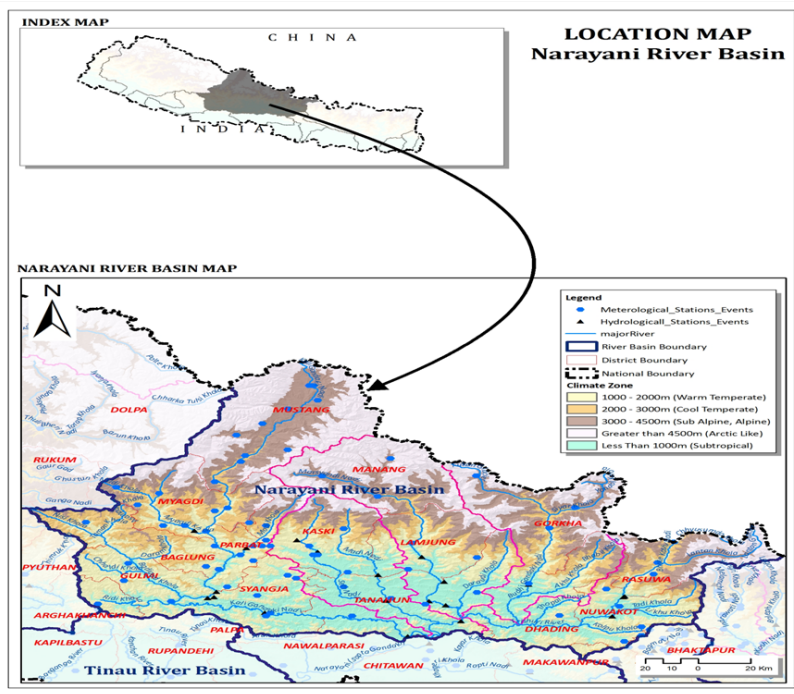

Figure 3: Narayani River basin

\subsection{West Rapti River}

The West Rapti River is a medium class river that originates from Mahabharat hills. The headwater of the river is located in Rolpa and Pyuthan districts at an altitude of 3,000 m. Jhimruk and Madi River are two major tributaries of the River.

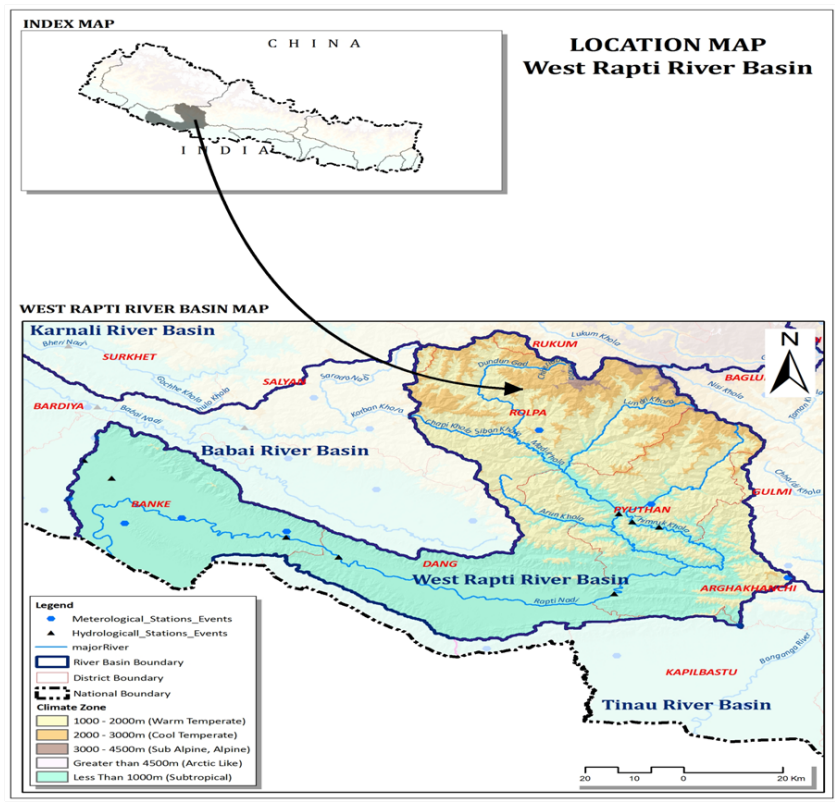

Figure 4: West Rapti River basin
The river also brings sediment-laden water from Churiya (Shiwalik) hills and erodes and inundates hundreds of hectares of land. The deposit of eroded material in the Terai plains results braiding of river. Moreover, it enhances lateral shifting, which has become a common trait for West Rapti River. Many small ephemeral rivers namely Khairi Khola, Munguwa Khola, Jhinjari Khola, and Dunduwa join the West Rapti River. The total length of the river is $257 \mathrm{~km}$. catchment area of the river is estimated $3747 \mathrm{~km}^{2}$ near east-west highway at Bhalubang [Fig.4]. This river is perennial in nature and its source of water is primarily the surface run off and ground water recession.

\subsection{Karnali River}

The Karnali River is a first class category river that originates from Himalyas [Figure 5]. It is a perennial, torrential, turbulent and undisturbed river. It originates from Tibet, perpetually snow covered Himalayan mountains.

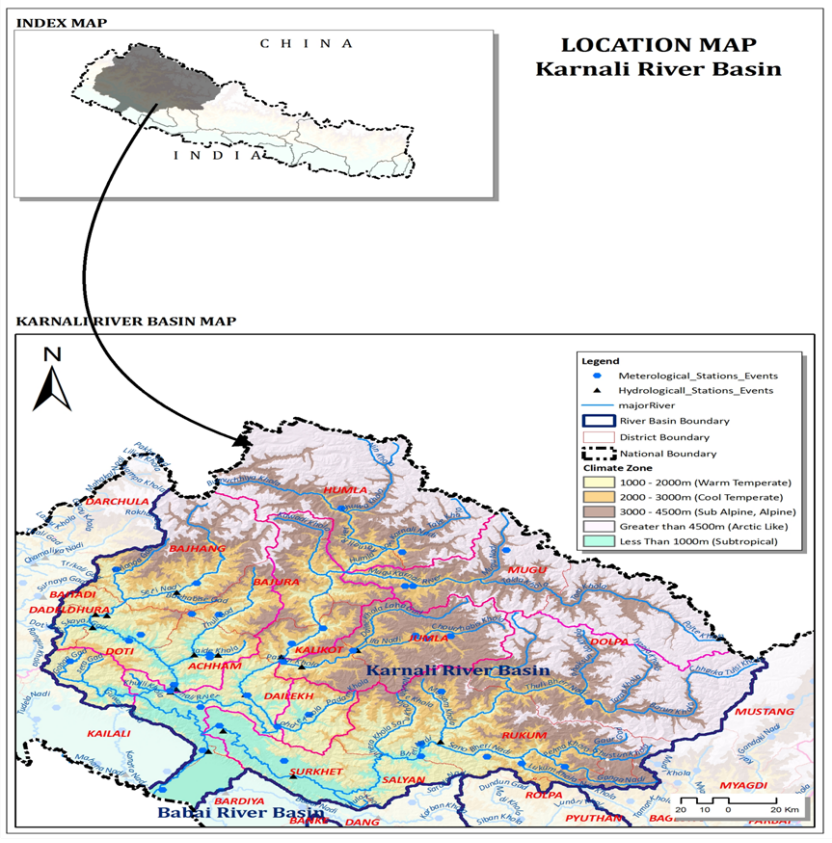

Figure 5: Karnali River basin

The Karnali basin lies between the mountain ranges of Dhaulagiri and Nanda Devi, in the western part of Nepal. The Karnali River is the longest river in Nepal, with a length of $507 \mathrm{~km}$. This River drains approximately $43,000 \mathrm{~km}^{2}$ before it enters to India. The major problems of river are: Bank erosion, sedimentation in riverbed area and farmland, flooding and inundation, river course shifting due to which 
important infrastructures facilities like road, canal, households, and farmland damages every year. Inundation spreads over hundreds of hectares land, is highly appeared in low elevated depressed land.

\subsection{Mahakali River}

Mahakali River a snow fed Perennial River. It flows along the Indo-Nepal boarder [Figure 6]. There are cultivated lands in both side of Mahakali River in Nepal part, whereas it passes through dense forest in Indian territory. The area, which lies in Nepal, is used as cultivated land and is low laying area. The major tributaries of this River are Chameliya Khola, Suryanaya Gad, and Rangoon Khola. The average length of Mahakali River is $211 \mathrm{Km}$. It originates from Api Himal. The River starts from Milan Glacier in India and forms the northern face of Lipulekh near Chhyanala pass in Darchula district. The total catchment area is about $15,440 \mathrm{~km}^{2}$ of which about $5,625 \mathrm{~km}^{2}$ lies in Nepal and remaining in India. The River is calm and erosive in nature. Irregular meandering is observed in a few stretches. The River behaves as a degrading River. It has deposited a huge amount of silt and debris in Terai belt.

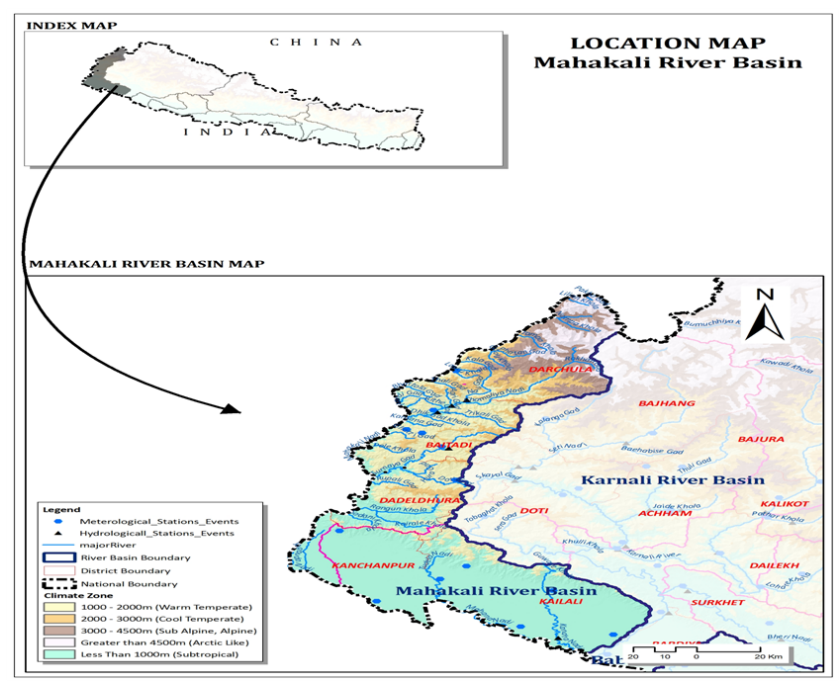

Figure 6: Mahakali River basin

\section{Materials and methods}

The study was carried out by a combination of field visits and a review of the designs of the bank protection works as described in different design reports. For the review of the performance and possible improvements of the bank protection works along the major Terai rivers, the different available master plans were reviewed [Table 1]. In all master plans, it was explicitly assumed that it is needed to construct embankments. While reviewing the master plans it was noticed that these plans aim for flood protection by embankments, but no drainage facilities are included.

Table 1: Overview of master plans and design reports

\begin{tabular}{|l|l|}
\hline River & Master plan study / Design report \\
\hline Koshi & $\begin{array}{l}\text { Department of Water Induced Disaster } \\
\text { Project (2009) }\end{array}$ \\
\hline Narayani & $\begin{array}{l}\text { North Star Engineering Consultant (P) } \\
\text { Ltd. (2010) } \\
\text { Water Asia (P) Ltd. Consulting Engineers } \\
(2004)\end{array}$ \\
\hline West Rapti & $\begin{array}{l}\text { Nepal Consult (P) Ltd. JV Research } \\
\text { Engineers Consultant, Everest } \\
\text { Engineering Consultants, and RIDA (P.) } \\
\text { Ltd. (2007) }\end{array}$ \\
\hline Karnali & $\begin{array}{l}\text { Manisha Engineering Management } \\
\text { Consultants (P.) Ltd. (2011) }\end{array}$ \\
\hline Mahakali & $\begin{array}{l}\text { Department of Water Induced Disaster } \\
\text { Prevention (2011) }\end{array}$ \\
\hline
\end{tabular}

\section{Results and discussions}

\subsection{Observations on rivers}

The major rivers when debouching from the upstream hills have cobble-gravel beds and are often armoured. Only the Koshi and the West Rapti show a clear transition to a sandier river. All major rivers in the Terai are fairly steep (in the order of $1 \mathrm{~m} / \mathrm{km}$ ) and hence will have high flow velocities during the flood season [2]. The planform of the major rivers is braided. In the Inner Terai the planform development is confined due to the presence of the hills. Some rivers show a transition to a more meandering planform more downstream [Fig.7].

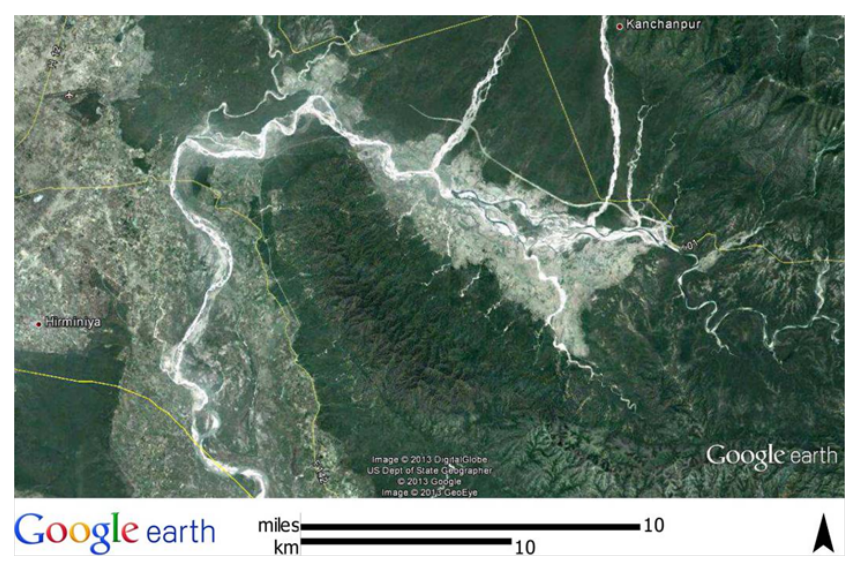

Figure 7: Planform of the West Rapti River 
The Karnali within the Terai splits in two major channels [Figure 8]. During low flow conditions, the channels appeared to be fairly shallow. Velocity might be in the order of 4.5 to $5 \mathrm{~m} / \mathrm{s}$, which seems quite high considering the roughness of the cobbles and gravel, which make up the bed of the river. Often sand bars and islands are present in the rivers. Sometimes the islands are covered with forest suggesting that they are a semi-permanent nature and have existed already in the order of a decade.

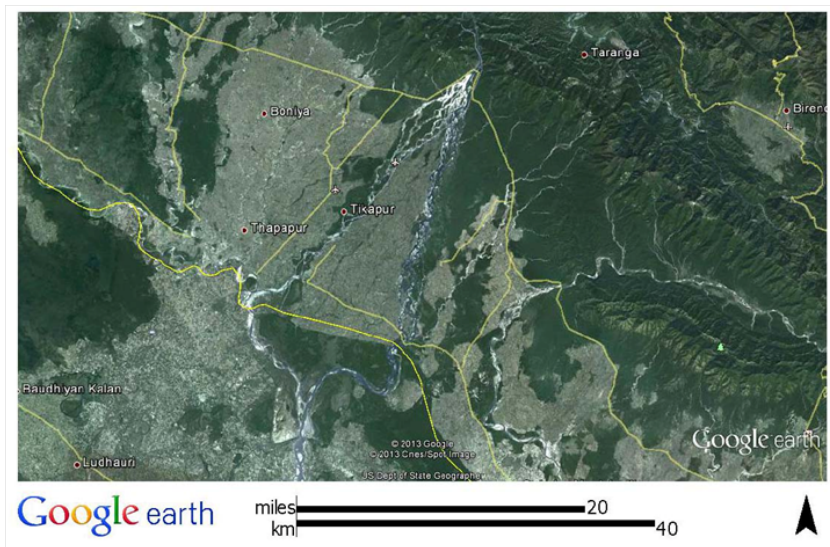

Figure 8: Karnali River splitting up in two branches

\subsection{Observations on embankments}

At many places embankments and spurs have been constructed recently or authorities are planning to construct. These embankments, spurs are made of local material. Grass protects their inner slope whereas gabions or sand bags were used to protect outer slope [Figures 9, 10, 11, 12, 13].

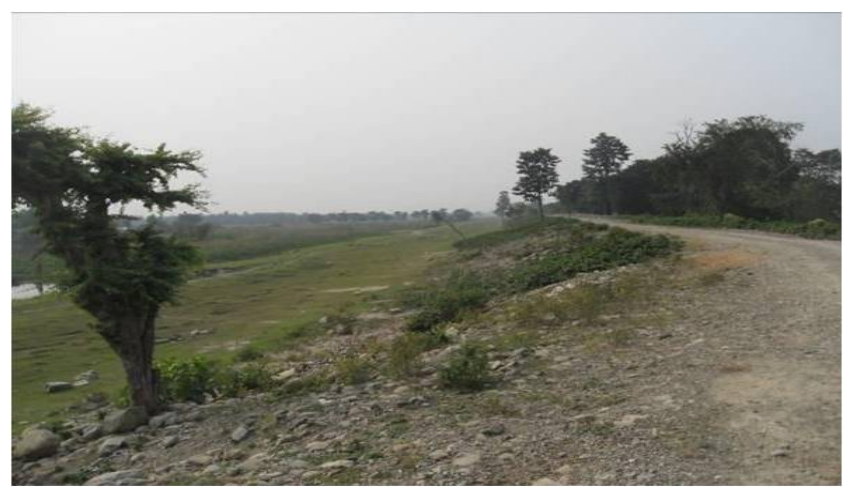

Figure 9: East embankment (Koshi River)

Top width of embankments was observed in the order of $5 \mathrm{~m}$ and the height of the embankments as required. Embankment levels seem to be based on historical flood levels or HEC-RAS simulations. Freeboard of the embankment is presumed $1 \mathrm{~m}$. In most cases embankments have been built directly on the edge on the banks of the river and often are integrated with bank protection works.

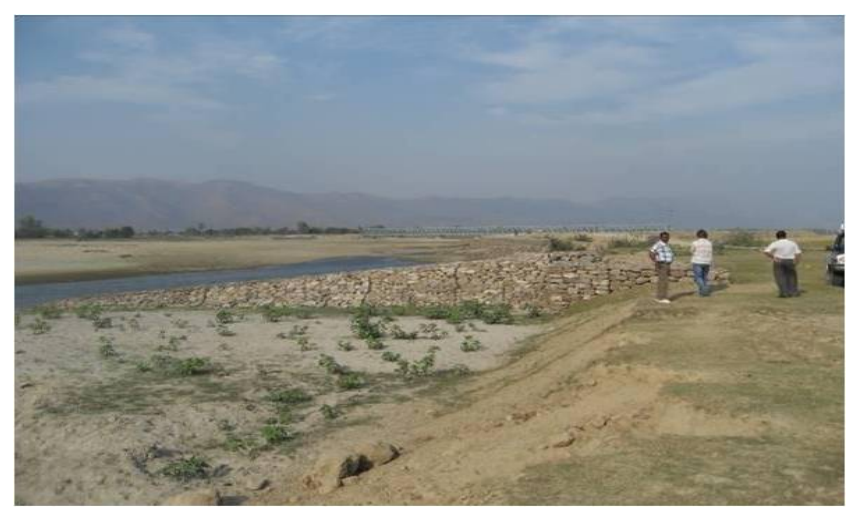

Figure 10: Spur with inclined crest (Narayani River)

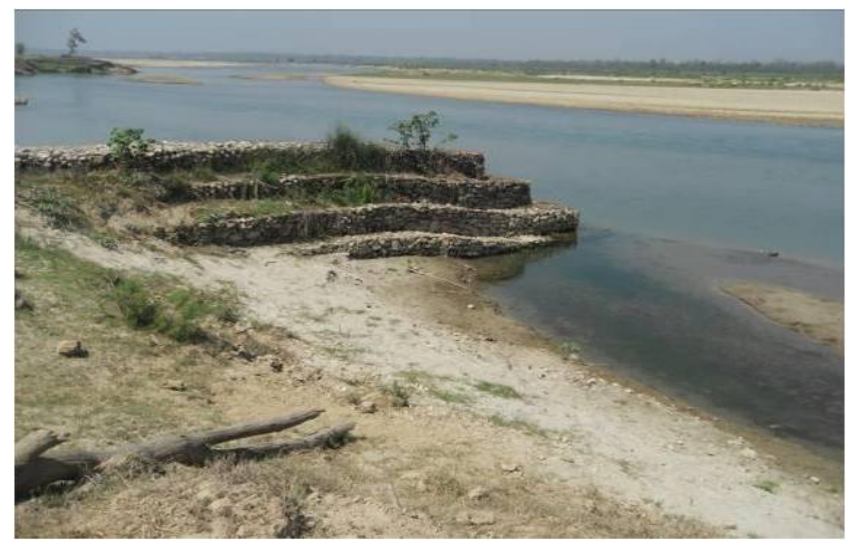

Figure 11: Isolated spur with no revetment (West Rapti River)

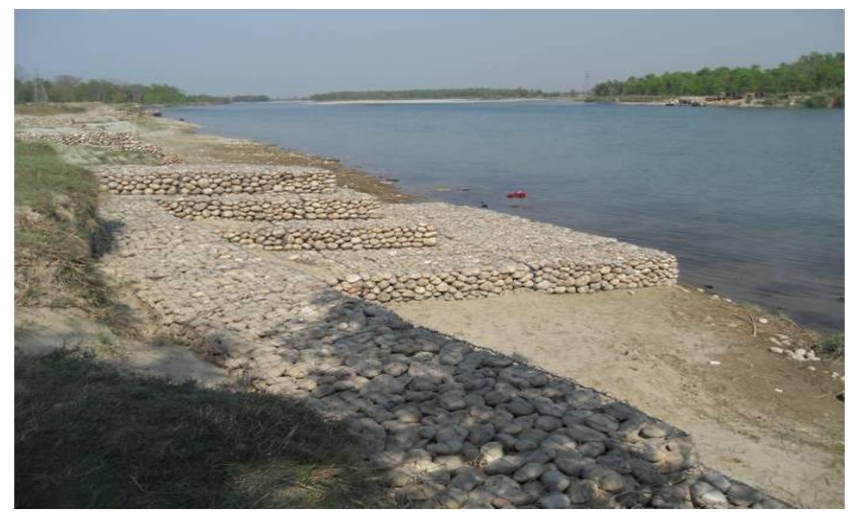

Figure 12: Revetment with falling apron (Karnali River) 


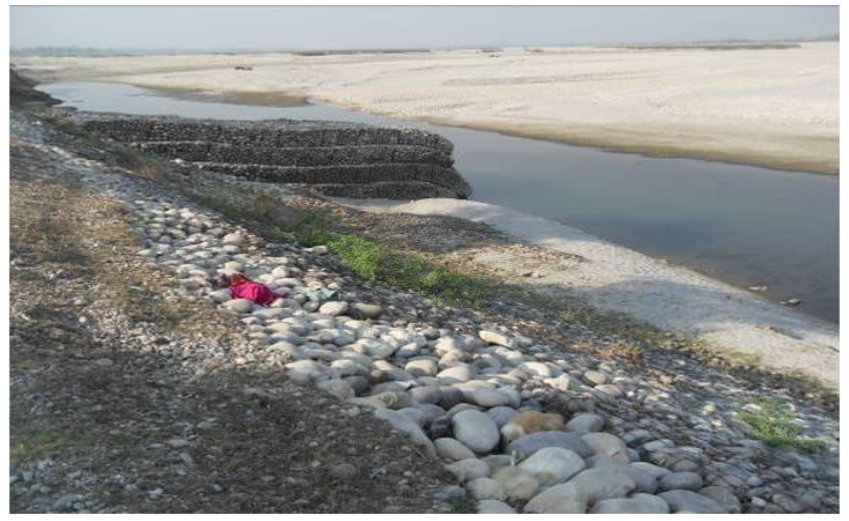

Figure 13: Spur protection embankment (Mahakali River)

\subsection{Observations on bank protection works}

Bank protection works often are revetments with short spurs. Also isolated spurs are present. In some cases isolated spurs were present with some supporting protection to prevent attack on embankments in between. Distance between spurs seems to be in the order of 2 to 2.5 their length, which is in line with existing guidelines. Spurs are not excessively long, and hence the bank protection works on one side of the river do not affect the other bank in a negative way. Spurs and revetments are exclusively made of gabions. Only in the most downstream reach of the West Rapti River bamboo structures were observed, which apparently are only for temporary works. Gabions dimensions were often $3 \mathrm{~m} \times 1 \mathrm{~m} \times 0.3 \mathrm{~m}$. Earlier always so-called solid spurs (crest level well above flood level) were used; nowadays gently inclined partly submersible spurs are applied [Figure 14]. Such inclined spurs induce a less sharp transition in velocity from river to bank and might reduce the van Karman eddies often responsible for deep scour holes. No damage on the shanks was observed; hence these spurs might work properly, even when they are overtopped. No data are available from field measurements of scour depths in front of spurs and apparently such measurements also have never been carried out either. Apparently the nose of the spurs is protected by falling aprons, which often seem to consist of horizontal gabions, which are connected with the body of the spurs by steel wires. Often the failure of the spurs starts at the nose, which suggests that this launching does not function properly. Hardly any maintenance is carried out, so initial failures of the spurs and revetments are not stopped timely. In all Terai Rivers, apart from the Koshi River where the maintenance seems to be acceptable, the lifetime of spurs and revetments made of gabions does not exceed
10 year and often already after one or a few flood seasons the bank protection works fail to properly check bank erosion.

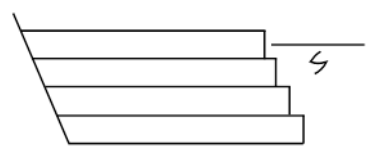

(a)

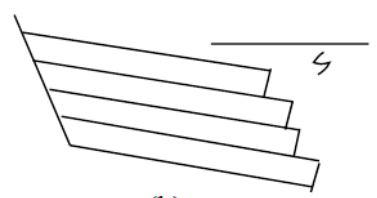

(b)
Figure 14: Types of spurs in use

(a) Originally non-submersible spur

(b) Recently applied inclined submersible spur

\subsection{Review on design methods and parameters}

The study overviews design methods used and in particular the design equations. The design methods deal in particular with the design parameters- design discharge, waterway width, scour depth, size bank protection elements, launching apron dimensions, spur lay-out, embankments [Table 2].

The design methods used for all different rivers are similar and correspond to Indian standards. This design method is based on the Lacey depth and width. Input variables are the design discharge $\mathrm{Q}$ and the silt factor ' $\mathrm{f}$ ' via $\mathrm{d}_{50}$ (in $\mathrm{mm}$ ). The recurrence interval for the determination of design discharge is 50 years for most rivers and 100 years for the Koshi River. The method to determine the design discharge is based on Gumbel distribution. In case of Mahakali River, the highest flood on record is used for design purpose. For the branches of the Karnali River, 2/3 of the design discharge is used. Central in the design is the determination of the scour depth, which is a certain factor (here always 1.5 is used) times the Lacey 3D depth. For the design velocity, two equations are used, where the design velocity according to Kennedy is much higher than the Lacey velocity. Neither is used in the design of the gabions, which seems to be fairly standard in dimensions applied. The freeboard used varies between 1.5 and $1.8 \mathrm{~m}$.

\subsection{Comparison of design approach with existing literatures}

An overview of the design boundary conditions for the different Terai rivers is presented in [Table 2]. Four design boundary conditions namely discharge, scour depth, velocity and waterway width are reviewed and compared with existing literatures. 
Table 2: Design methods and parameters

\begin{tabular}{|c|c|c|c|c|c|c|c|c|c|}
\hline \multirow{3}{*}{$\begin{array}{c}\text { Design } \\
\text { parameter }\end{array}$} & \multirow{3}{*}{\multicolumn{2}{|c|}{ Parameter }} & \multirow{3}{*}{ Formula used } & \multicolumn{6}{|c|}{ Rivers } \\
\hline & & & & \multirow[t]{2}{*}{ Koshi } & \multicolumn{2}{|c|}{ West Rapti } & \multirow[t]{2}{*}{ Narayani } & \multirow[t]{2}{*}{ Karnali } & \multirow[t]{2}{*}{ Mahakali } \\
\hline & & & & & $\begin{array}{l}\text { Upper } \\
\text { reach }\end{array}$ & $\begin{array}{l}\text { Lower } \\
\text { reach }\end{array}$ & & & \\
\hline \multirow[t]{3}{*}{$\begin{array}{l}\text { Design } \\
\text { discharge }\end{array}$} & \multicolumn{2}{|c|}{$\begin{array}{l}\text { Recurrence interval } \\
\text { design flood (year) }\end{array}$} & & 100 & 50 & 50 & 50 & 50 & $\begin{array}{c}\text { Maximum } \\
\text { recorded } \\
\text { Q in } 1934\end{array}$ \\
\hline & \multicolumn{2}{|c|}{ Extrapolation method } & & Gumbel & Gumbel & Gumbel & Gumbel & $\begin{array}{l}\text { Gumbel } \\
\text { (GEV) }\end{array}$ & \\
\hline & \multicolumn{2}{|c|}{ Design flood $\left(\mathrm{m}^{3} / \mathrm{s}\right)$} & & 22512 & 6,166 & 8,286 & $\begin{array}{rl} & 1.15 \\
* & 15652 \\
= & 18000\end{array}$ & $\begin{array}{c}2 / 3 \% \text { of } \\
\mathrm{Q}_{50}= \\
2 / 3 * 17151 \\
=11435\end{array}$ & 15000 \\
\hline \multirow{2}{*}{$\begin{array}{l}\text { Waterway } \\
\text { width }\end{array}$} & \multicolumn{2}{|c|}{ Lacey width (m) } & $P=4.75 \sqrt{Q}$ & 720 & 373 & 433 & 637 & & \\
\hline & \multicolumn{2}{|c|}{ Waterway design (m) } & $W=X_{1} P$ & & $\mathrm{X}_{1}=3$ & $\mathrm{X}_{1}=3$ & $\mathrm{X}_{1}=3$ & $\mathrm{X}_{1}=2.5$ & $\mathrm{X}_{1}=3$ \\
\hline \multirow[t]{4}{*}{ Scour depth } & \multicolumn{2}{|l|}{$\mathrm{D}_{50}(\mathrm{~mm})$} & & 10 & & $0.18-0.59$ & & 2.49 & \\
\hline & \multicolumn{2}{|c|}{$\begin{array}{l}\text { Silt factor } \mathrm{f} \text { (note that } \\
\mathrm{D} 50 \text { is in } \mathrm{mm} \text { ) }\end{array}$} & $f=1.76 \sqrt{D_{50}}$ & 5.56 & $\begin{array}{l}5.28-4.31 \\
(\text { avg } 4.85)\end{array}$ & $\begin{array}{l}(0.40- \\
2.75) \\
\text { avg } 1\end{array}$ & 2.5 & 2.78 & 2 \\
\hline & \multicolumn{2}{|c|}{ Lacey depth (m) } & $R=0.473\left(\frac{Q}{f}\right)^{1 / 3}$ & 7.52 & 5.12 & 9.54 & 9.10 & 7.58 & 9.23 \\
\hline & \multicolumn{2}{|c|}{ Scour depth (m) } & $d_{s}=X_{2} R$ & $\mathrm{X}_{2}=1.5 \mathrm{R}$ & $\begin{array}{l}\text { Nose: } \mathrm{X}_{2}= \\
2.0-2.5 \mathrm{R}\end{array}$ & $\begin{array}{l}\text { Nose: } \mathrm{X}_{2}= \\
2.0-2.5 \mathrm{R}\end{array}$ & $\begin{array}{l}\text { Nose: } \mathrm{X}_{2} \\
=2.0 \mathrm{R}\end{array}$ & $\begin{array}{l}\text { Nose: } \mathrm{X}_{2} \\
=2.0 \mathrm{R}\end{array}$ & $\begin{array}{l}\text { Nose: } \mathrm{X}_{2} \\
=2.0 \mathrm{R}\end{array}$ \\
\hline \multirow{2}{*}{$\begin{array}{l}\text { Size bank } \\
\text { protection }\end{array}$} & \multirow{2}{*}{$\begin{array}{l}\text { Design } \\
\text { velocity }(\mathrm{m} / \mathrm{s})\end{array}$} & Lacey & $u=0.44 Q^{1 / 6} f^{1 / 3}$ & 1.32 & 1.113 & 1.98 & 3.03 & 2.94 & 2.75 \\
\hline & & Kennedy & $u=m R^{0.54}$ & 3.64 & 2.84 & 4.23 & 4.11 & 4.39 & 4.16 \\
\hline \multirow[t]{4}{*}{$\begin{array}{l}\text { Launching } \\
\text { apron }\end{array}$} & \multicolumn{2}{|c|}{$\begin{array}{l}\text { Launching apron } \\
\text { thickness (launched) }\end{array}$} & $1.25 \mathrm{~T}$ & 0.375 & 0.3 & 0.3 & 0.3 & 0.3 & 0.30 \\
\hline & \multicolumn{2}{|c|}{$\begin{array}{l}\text { Launching apron } \\
\text { thickness (un-launched) }\end{array}$} & $1.9 T$ & $\begin{array}{l}\sim 0.60 \text { to } \\
1.0 \mathrm{~m}\end{array}$ & 0.375 & 0.375 & 0.375 & 0.375 & 0.375 \\
\hline & \multicolumn{2}{|c|}{$\begin{array}{l}\text { Length launching apron } \\
(\mathrm{m})\end{array}$} & $1.5 d_{s}$ & $1.5 \mathrm{~d}_{3}$ & $\begin{array}{l}0.60 \text { to } 1.0 \\
\mathrm{~m}\end{array}$ & $\begin{array}{c}0.60 \text { to } 1.0 \\
\mathrm{~m}\end{array}$ & $0.60 \mathrm{~m}$ & $0.50 \mathrm{~m}$ & $\begin{array}{l}0.50 \text { to } \\
0.60 \mathrm{~m}\end{array}$ \\
\hline & \multicolumn{2}{|l|}{ Length L (m) } & $L=3 \%$ river width & & $1.5 \mathrm{~d}_{8}$ & $1.5 \mathrm{~d}_{8}$ & $1.5 \mathrm{~d}_{3}$ & $1.5 \mathrm{~d}_{3}$ & $1.5 \mathrm{~d}_{3}$ \\
\hline \multirow[t]{4}{*}{ Spur lay-out } & \multirow{2}{*}{\multicolumn{2}{|c|}{$\begin{array}{l}\text { Length L (m) } \\
\text { Orientation }\end{array}$}} & $\begin{array}{lll}L<10 \% & \text { river } \\
\text { width } & & \\
\end{array}$ & & & & & & \\
\hline & & & & \multicolumn{3}{|c|}{ Transverse to flow } & $\begin{array}{c}1 / 10 \text { of } \\
\text { river } \\
\text { width }\end{array}$ & $\begin{array}{c}1 / 10 \text { of } \\
\text { river } \\
\text { width }\end{array}$ & \\
\hline & \multicolumn{2}{|l|}{ Spacing S (m) } & $S=(3-4) L$ & $3 \mathrm{~L}$ & $\begin{array}{c}\text { Transverse } \\
\text { to flow }\end{array}$ & $17.5^{\circ}$ & $\begin{array}{c}\begin{array}{c}\text { Transverse } \\
\text { to flow }\end{array} \\
\end{array}$ & $\begin{array}{c}\text { Transverse } \\
\text { to flow }\end{array}$ & $\begin{array}{c}\text { Transverse } \\
\text { to flow }\end{array}$ \\
\hline & Top width (m) & & & & $(3-4) \mathrm{L}$ & $(3-4) \mathrm{L}$ & $(2-3) \mathrm{L}$ & $(2-2.5) \mathrm{L}$ & $(3-4) \mathrm{L}$ \\
\hline Embankments & River slope & & & & $2.5-5$ & $2.5-5$ & 6 & 5 & 6 \\
\hline & Land slope & & $B I S$ & & $1 \mathrm{~V}: 2 \mathrm{H}$ & $1 \mathrm{~V}: 2 \mathrm{H}$ & $1 \mathrm{~V}: 2 \mathrm{H}$ & $1 \mathrm{~V}: 2 \mathrm{H}$ & $1 \mathrm{~V}: 1 \mathrm{H}$ \\
\hline & Freeboard (m) & & & & $1 \mathrm{~V}: 2 \mathrm{H}$ & $1 \mathrm{~V}: 2 \mathrm{H}$ & $1 \mathrm{~V}: 2 \mathrm{H}$ & $1 \mathrm{~V}: 2 \mathrm{H}$ & $1 \mathrm{~V}: 2 \mathrm{H}$ \\
\hline
\end{tabular}




\subsubsection{Design discharge}

In a braided river the discharge is divided over different channels. In [Table 2] it is assumed that the design discharge corresponds to the design discharge of the river. However, the discharge in a braided channel is divided over different channels; hence the design discharge of the attacking channel is less. In the FAP21 Guidelines and Manual it is proposed to determine the flood discharge of the attacking channel with the following formula [Eq-1], which assumes that the design discharge is $50 \%$ higher than when the design flood would be divided over the number of channel present in the cross-section.

$$
Q_{d, c h}=\frac{C_{1}}{k} \times Q_{d, t}
$$

Where,

$Q_{d, t}=$ Total design discharge (m3/s),

$Q d, c h=$ Design discharge of the attacking channel $\left(\mathrm{m}^{3} / \mathrm{s}\right)$,

$C_{1}=$ Safety factor, recommended value is $C_{1}=1.5$,

$k=$ braiding index.

This equation can also be written in terms of the relative discharge and plotted [Fig.10].

$$
\frac{Q_{d, c h}}{Q_{d, t}}=\frac{C_{1}}{k}
$$

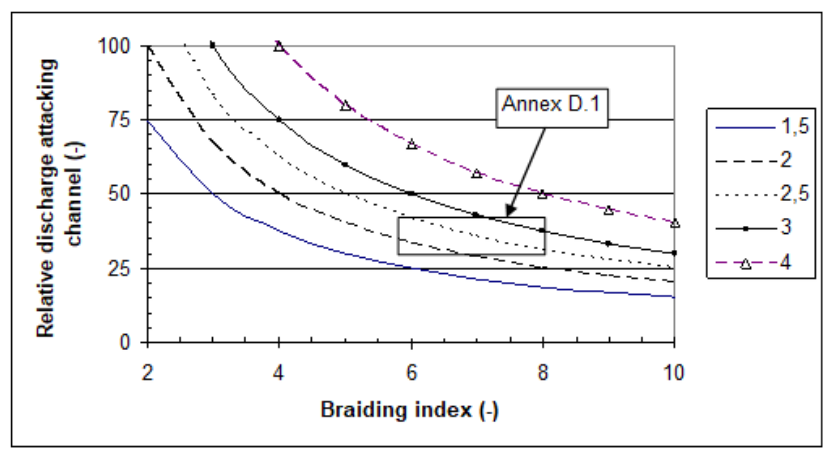

Figure 15: Relative discharge as function of braiding index and safety factor (FAP21/22)

It can be concluded that for Terai Rivers with a braiding index of say 2 to 4 and a safety factor of 1.5 as suggested by Flood Action Plan (FAP) 21/22 [Fig.15], that the design discharge of one channel would vary 40 and $60 \%$ of the design discharge of the river as a whole. A reduction of $50 \%$ of the design discharge of a channel will result in a reduction of about $15 \%$ of the Lacey depth [Figure 10], which is the basis for the design scour depth.

\subsubsection{Design scour depth}

In the existing design, assessment of the reference channel depth is made using Lacey's approach. The silt factor in the equation is determined by d50 of the bed material. This d50 however varies substantially along the rivers. How to deal with such a large variation in one master plan is a matter of engineering judgement. The silt factors applied for the different rivers vary between 2 and 5.56. To determine the scour depth, Lacey depth is multiplied with multiplication factors, which are dependent on the location of the protection in the bend, how sharp the bend is, type of protection, etc. The ratio (ho + hs )/h3 ranged from 1.6 to 3.9 , and Inglis (1947) recommends the use of the different multiplication factors for different conditions [Table 3]. In existing design, the scour depth is consistently computed as 1.5 times Lacey depth. To this, the existing depth still has to be added to arrive at the scour level below the design water level. For spurs the multiplication 3.8 applies (Inglish, 1947). Hence, in the master plans, the scour depth thus obtained might be underestimated. Some compensation is available in that the total discharge was used and not the design discharge for a single channel.

Table 3: Multiplication factors [15]

\begin{tabular}{|l|c|}
\hline Conditions & $\begin{array}{c}\text { Multiplication } \\
\text { Factor }\end{array}$ \\
\hline $\begin{array}{l}\text { Scour at straight spur dikes angled } \\
\text { upstream with steeply sloping noses } \\
(1.5 \mathrm{~V}: 1 \mathrm{H})\end{array}$ & 3.8 \\
\hline $\begin{array}{l}\text { Scour at similar dikes but with long } \\
\text { sloping noses }\end{array}$ & 2.25 \\
\hline $\begin{array}{l}\text { Scour at guide bank noses of large- } \\
\text { radius }\end{array}$ & 2.75 \\
\hline
\end{tabular}

\subsubsection{Design flow velocity}

In the existing design, flow velocity varies per river and per prediction method applied. Range of design velocities varies from 1.1 and $4.4 \mathrm{~m} / \mathrm{s}$. For gabions this does not make much difference because flow velocity does not determine the gabion size. However, for future revetments with rock or geo-bags, proper insight in the design velocities is required. The size of the rock and the weight of the geo-bag for the slope protection are 
very sensitive to the assumed design flow velocities. Measurements during flood are required to substantiate the assumed velocities.

\subsubsection{Design waterway depth}

For all master plans, the design waterway is determined as three times Lacey width. The logic behind this is that some parts of the floodplain have to be kept for conveyance and flow of extreme floods. The Lacey width underestimates the width of natural channels substantially. Author have some doubts whether even this fairly narrow width in practice is maintained in view of the pressure of the local population to built the embankments as near to the river as possible. Steady and unsteady HEC-RAS simulations can be used to arrive at better estimates of the required waterway width. Also floodplain sedimentation has to be considered.

\subsection{Reasons of failure of protection works}

Traditionally gabions are used for bank protection works. Gabions are made up of steel wire crates, which are filled up by stones. Gabions have as advantage that they can be produced with almost any weight. The weight of a protective element is its determining factor for its stability and it scales with the velocity to the power 6 . For velocities of $4 \mathrm{~m} / \mathrm{s}$ and more, there is hardly an alternative comparable to gabions. Gabions have also distinct disadvantages. Minor changes in the underground and or the support of gabions cause deformation of the gabion and additional stresses on the mesh, which might result in breaking and a disintegration of the gabion. Another disadvantage is that the quality of the mesh wire deteriorates over time. These two negative factors might contribute to the early failure of individual gabions and a subsequent disintegration of the spurs and revetments.

Launching aprons are supposed to launch when the scour depth in front of the structure reaches lower levels than the toe level of the bank protection. Usually, launching aprons are made up of loose material, often boulders or in some cases concrete blocks. Geo-bags are used which launch under slope of $1 \mathrm{~V}: 2.5 \mathrm{H}$, which is attractive for the geotechnical stability of the protected banks. Because the launched layer is only one geo-bag thick additional geo-bags are placed on the launched geo-bags resulting a new launching apron is constructed at a lower level. In this way, the bank protection is built up in a number of years. This approach accounts for an increased attack on the banks over a number of subsequent years, which is quite common for braided rivers. The disadvantage of gabions as launching apron is that most probably they do not launch. Due to the toe erosion, the gabion is undermined and is not able to follow the decreasing bed levels. Thus created bending causes the gabion to break with again a subsequent disintegration of the spur.

Hence, main reasons of early spurs failure are due to some basic flaws in the design. The spur cannot cope with toe erosion and collapses once this happens. Scour holes in front of spurs in the upstream reaches of the Terai rivers might be limited due to the graded character of the bed material but in the sandy reaches the scour depth can be substantial.

\section{Conclusions and recommendations}

\subsection{Conclusions}

A review was carried out of the performance of bank protection works constructed over the last decades along the major Terai Rivers. The study reveals main reasons of early spurs failure are due to some basic flaws in the design. Summary of study findings are outlined below.

i) Bank protection works along the major Terai rivers in Nepal consist almost exclusively of spurs often combined with revetments in between, made of gabions filled with boulders. Also the launching aprons are constructed of gabions. The lifetime of these bank protection works is less than 10 years and often much shorter.

ii) Although it is difficult to determine the cause of the quick failure of the bank protection works without detailed further studies, in many cases the failure is caused by the occurrence of large scour holes in combination with the not proper launching of the gabions. Due to this the gabions are subjected to large stresses resulting in their disintegration, which subsequently in a number of steps results in a total failure of the spurs. Apart from the Koshi River spurs and embankments, monitoring and maintenance of the bank protection works is not carried out in a systematic way.

iii) Designs are based on standard designs from Indian standards, developed for "normal" alluvial 
rivers (not for braided rivers on alluvial fans with steep slopes and quick change in particle size distribution) and might not be applicable. No field measurements have been carried out to verify the design boundary conditions (discharge of the attacking channel, scour depths, local velocities, etc.)

iv) The master plans all start from the presumption that embanking is a good strategy. The master plans are deficient in a number of aspects, related to the alignment of the embankments, drainage facilities and embankment levels in relation to future flood levels. The economic feasibility of the embankments schemes as determined in the master plans is too optimistic: life time of the bank protection works is much less than assumed (25 years), maintenance is underestimated.

\subsection{Recommendations}

On the basis of quick review and the conclusions, the following recommendations are made.

i) A bank protection pilot project should be initiated in which the cause of the failure of the bank protection works is identified and remedial measures are tested. The ultimate aim of such a pilot project would be the development of bank protection works, which with proper and timely maintenance could last several decades rather than several years, as is now the case. Revetments without spurs might be preferable, because these results in lower velocities near the bank and less deep scour holes. In such a pilot project, other bank protection techniques should be tested. One possible technique is revetments made up of large geo-bags below the low water line and e.g. gabions above the low waterline, constructed using an adaptive approach as applied in Bangladesh.

ii) Field measurements should be carried out to assess the design boundary conditions in the Terai rivers. The embankments should not be built on the edge of the bank of the river. Some safety distance between bank protection works and embankments should be provided for. Drainage facilities should be supplied and drainage within the embanked areas should be optimised (via bridges and culverts). Embankment levels and overall design of the embankments should be determined considering the future rise of flood levels in these rivers on alluvial fans, when and where appropriate.

iii) Aggradation and degradation rate in Terai rivers in Nepal are not observed the same and some might even not aggrade at all. That depends on the balance between sediment supply and subsidence. The design aspect especially width of waterway, height of levees, spurs etc. considered in this study doesn't incorporate the aggradation and degradation of river including sediment transportation. In author's view, a proper study should be made in future to addresses this aspect.

iv) While reviewing the master plans it was noticed that these plans aim for flood protection by embankments, but no drainage facilities are included. Drainage is required to drain excess water due to local rainfall during the flood season. Moreover, local rivers might bring in substantial quantities of water which might not be stored in the embanked area. When a breach occurs and subsequently the area behind the embankment is flooded, it should be possible to release the water in the flooded are once the river has receded again. If not sufficient drainage facilities are provided, water logging may occur and the local population will try to solve this by making artificial breaches. Only by providing sufficient drainage facilities such problems can be prevented. In each master plan a separate study into drainage facilities and their required capacity should be included.

\section{References}

[1] E. Hooning, "Flooding and sediment management on the Koshi alluvial fan, Nepal," Master's thesis, Delft University of Technology, Netherland, 2011.

[2] A. Dixit, "Floods and vulnerability: need to rethink flood management," Flood problem and management in South Asia, vol. 28, pp. 155-179, 2003.

[3] A. Colombo, J. Hervás, and A. L. Vetere Arellano, "Guidelines on flash flood prevention and mitigation," European Commission Joint Research Centre (JRC), Tech. Rep., 2002.

[4] V. Vanoni, "Sedimentation engineering, manuals rep. eng. pract., vol. 54," Am. Soc. of Civ. Eng., Reston, Va, 1975. 
[5] P. Jansen, Principles of River Engineering, The non-tidal alluvial river. Pitman, London, 1979.

[6] C. V. J. Varma, K. R. Saxena, and M. Rao, River behaviour management and training, Central Board of Irrigation and Power, New Delhi, India, 1989, vol. 1 and 2.

[7] R. J. Garde and K. R. Raju, Mechanics of sediment transportation and alluvial stream problems. Taylor \& Francis, 2000.

[8] M. Garcia, "Sedimentation engineering: processes, measurements, modeling, and practice," in ASCE Manual on Engineering Practice No. 110. American Society of Civil Engineers, 2008.

[9] Q. Q. Shang, H. Xu, and G. B. Li, "Overview of research on the influence of permeable structures," in Applied Mechanics and Materials, vol. 405. Trans Tech Publ, 2013, pp. 2115-2122.

[10] H. Nakagawa, H. Teraguchi, K. Kawaike, Y. Baba, and H. Zhang, "Analysis of bed variation around bandal-like structures," Annu. Disas. Prev. Res. Inst., vol. 54, no. B, pp. 497-510, 2011.
[11] M. Rahman, H. Nakagawa, T. Ishigaki, and A. Khaleduzzaman, "Channel stabilization using bandalling," Annu. Disas. Prev. Res. Inst., vol. 46, no. B, pp. 613-618, 2003.

[12] M. L. Rahman, B. Basak, and M. S. Osman, "Velocity distribution around bandalling for navigation channel development," in Int. Conf. Mechanical Engineering, 2011.

[13] H. Zhang, H. Nakagawa, Y. Baba, K. Kawaike, and H. Teraguchi, "Three-dimensional flow around bandal-like structures," Annual Journal of Hydraulic Engineering, JSCE, vol. 54, pp. 175-180, 2010.

[14] M. Akhtar, N. Sharma, and C. Ojha, "Braiding process and bank erosion in the brahmaputra river," International Journal of Sediment Research, vol. 26, no. 4, pp. 431444, 2011.

[15] C. C. Inglis, Behaviour and control of rivers and canals (Chapter 9: The design of falling apron). Central Waterpower Irrigation and Navigation Research Station, Pune \& Library of Institution of Civil Engineer, London, U.K, 1949. 
